\begin{tabular}{c} 
Volume and Issues Obtainable at Center for Sustainability Research and Consultancy \\
Review of Politics and Public Policy in Emerging Economies \\
ISSN: 2708-3829 (E): 2708-356X \\
Volume 1: No. 1, June 2019 \\
CSRᄃ \\
Journal homepage: www.publishing.globalcsrc.org/rope \\
\hline
\end{tabular}

\title{
The Legal Saga of Exclusion Clauses in Malaysia
}

\author{
1 Tan Pei Meng \\ ${ }^{1}$ Assistant Professor, Faculty of Accountancy and Management, Universiti Tunku Abdul Rahman, \\ Malaysia.tanpm@utar.edu.my
}

\begin{tabular}{l}
\multicolumn{1}{c}{ ARTICLE DETAILS } \\
\hline History \\
Revised format: May 2019 \\
Available Online: June 2019 \\
\hline
\end{tabular}

Keywords

Contract, Exclusion Clauses, S.29 Contracts Act 1950, Courts, Liability

\section{JEL Classification:}

L24, L29, K13

\begin{abstract}
One of the issues that could affect the success or the sustainability of a business organisation is its ability to manage the legal risk of liability that it faces in running its business. One common tool utilised by businesses is to insert an exclusion or limitation clause in their contracts. This would allow them to predict and apportion the possible amount of liability that could arise from breach of contract or negligence. The courts usually exercise caution in allowing such clauses to be enforced in order to prevent unfairness especially to the weaker party. Malaysia is of no exception. The Malaysian courts have display willingness to strike down the validity of an exclusion clause to ensure that a business organisation does not escape liability arising from its own fault. The Federal Court and the Court of Appeal decision in Bourke v CIMB Bank Bhd (2018) are good examples of such an approach. However, the legal reasoning adopted by the courts in this case has led to numerous confusions on the legal principles of contract law in Malaysia. It is therefore necessary to examine the legal position of exclusion clauses in Malaysia today and to determine what is the most appropriate way forward. This research found that there are difficulties with the legal coherency and application of Bourke in future cases.
\end{abstract}

\section{OPEN ACCESS}

(C) 2019 The authors, under a Creative Commons AttributionNonCommercial 4.0

Corresponding author's email address: tanpm@utar.edu.my

Recommended citation: Meng, T. P., (2019). The Legal Saga of Exclusion Clauses in Malaysia. Review of Politics and Public Policy in Emerging Economies, 1(1), 43-52

DOI: $10.26710 /$ rope.v1i1.1130

\section{Introduction}

Exclusion clauses can be defined as terms in a contract which exempt, modify or limit the contractual obligations or liability of one of the contracting parties. These clauses are one of the tools utilized by those in business to apportion the possible liability which could arise from the business transaction which they enter into in the course of their business. The use of such clauses would enable the parties to predict the amount of potential liability ad to make the necessary arrangements such as purchasing an insurance policy if necessary. The courts have given legal recognition to exclusion clauses due to the principle of freedom of contract where the contracting parties can determine the kind of terms they wish to insert into 
their contract. Since a contract is created as a result of consent by both parties, the courts would give effect to the terms of contract as long as the terms are not unlawful or against public policy. The sanctity of the contract should be respected. However, this assumption is only realistically true in relation to contracts entered into as a result of negotiation between both parties. The concept of freedom of contract was enunciated in the 19th century where standard form contracts were scarce unlike in today's business environment. There is no room for bargaining for standard form contracts which are often offered on a 'take it/ leave it' basis. In the light of the lack of negotiation in these contracts, the dominant party could take advantage and insert exclusion clauses which benefit themselves at the expense of the weaker party. This might lead to injustice in contract law if the validity of these clauses is upheld particularly where the weaker contracting party is a consumer. In Malaysia, the major statutory reform on unfair terms came as late as 2010 by the enactment of the Consumer Protection (Amendment) Act 2010. Prior to that, the Malaysian courts had controlled the use of exclusion clauses to avert any possible injustice with its own legal reasoning. However, the statutory reform on unfair terms is also fraught with difficulties as will be examined below. Hence, it is not surprising that the Malaysian courts still have to grapple with the issue as to whether an exclusion clause should be given effect based on common law principles to as seen in the recent Federal Court decision in CIMB Bank Bhd v Bourke [2019] 1 AMR 421. It is therefore necessary to determine whether the legal position of exclusion clauses has reached a satisfactory state or whether more has to be done to ensure legal coherency and adequate protection for weaker parties in a contract.

\section{Research Methodology}

In order to carry out this research, the author conducted a content analysis on both primary and secondary data obtained from library, databases and the internet to determine the legal issues surrounding exclusion clauses which plague the courts in Malaysia throughout all these years. This research also discovers the steps taken by the Malaysian Parliament in improving the law on this area. The primary data involved are the various legislations and judicial decisions in Malaysia. The secondary data includes, academic articles, conference papers, articles written by legal professionals and newspaper reports dealing with exclusion clauses.

\section{Legal Position on Exclusion Clauses Prior to 2010}

An exclusion clause is valid and enforceable if certain requirements are met. First, the exclusion clause has to be incorporated into the contract before or at the time it is created. Secondly, the scope of the exclusion is sufficiently wide to cover the losses or remedies claimed by the plaintiff (party who suffers losses or grievances). The Malaysian courts sought to control the use of exclusion clauses by adopting a strict interpretation or construction of exclusion clauses. One such case is Premier Hotel v Tang Ling Seng [1995] 4 MLJ 229. In Premier, the plaintiff was staying at the defendant's hotel. The defendant's employee had negligently given the key to the plaintiff's room to another person. As a result, the plaintiff's personal belongings were stolen. The defendant sought to seek refuge from liability by relying on the exclusion clause in its contract with the plaintiff which provided that '. . . hotel will not assume responsibility for valuables or money lost from the room.' It was held that the exclusion clause was not sufficiently drafted to cover liability due to negligence. Thus, the defendant was made liable. The lesson from this case is that if a party wish to exclude liability for negligence he has to state it clearly in the exclusion clause by utilizing words such as 'negligence' or 'whatsoever' or 'howsoever' caused.

A more controversial means to curtail the use of exclusion clauses is seen in the case of Sze Hai Tong Bank Ltd v Rambler Cycle Co Ltd [1959] AC 576 (Privy Council). Lord Denning in this case refused to give effect to the widely drafted exclusion clause relied on by the defendant. To do so would enable the defendant to escape liability for breach of its main obligation under the contract. His lordship added that there was a need to modify or limit the application of the exclusion clause where it should not apply if the loss was due to the serious negligence of the defendant. It is to be noted that Lord Denning's approach which was known as the doctrine of fundamental breach was disapproved by the House of Lords in Suisse Atlantique Societe d' Armament v NV Rotterdamsche Kolen Centrale [1967] 1 AC 361 and Photo Production v Securicor [1980] 1 All ER 556. As such, the doctrine of fundamental breach in relation to 
exclusion clauses was no longer applicable in England.

However, in Malaysia, the remnants of Lord Denning's judgment in Sze Hai Tong can be seen in the following cases. In The Taveechai Marine [1995] 1 AMR 330, the trial judge agreed that the contract made between parties cannot be interpreted so widely as to exclude the liability of the defendant for their own fault by referring to Sze Hai Tong. In Sekawan Guards Sdn Bhd v Thong Guan Sdn Bhd [1995] 1 MLJ 413, the exclusion clause provided that "The company shall not be liable for any loss suffered by the owner due to burglary, theft, fire, or any other cause whatsoever, unless such loss is solely caused by the negligence of the company's own employee acting in the course of their employment." It was held by the High Court that in order for the defendant to rely on this exclusion clause, it had to prove that it was not negligent.

In Chin Hooi Nan v Comprehensive Auto Restoration Service Sdn Bhd [1995] 2 MLJ 100, the High Court went further and held that despite how widely drafted the exclusion clause was, it could not absolve the defendant from liability unless the defendant proves that he had exercised due diligence and the loss cause is not due to his negligence or misconduct. Perhaps, the court in Chin Hooi Nan felt that there was a need to protect consumers who entered into standard forms contract as there was no statutory rules to protect consumers against unfair terms. It is unclear as to whether the same principle should apply in relation to business to business contracts (B2B).

Another possible method to overcome the exclusion of liability is by arguing that the exclusion clause is void due to the doctrine of inequality of bargaining position between the parties. In Saad Marwi v Chan Hwan Hua [2001] 3 CLJ 98, the Court of Appeal for the very first time in Malaysia recognized that this doctrine could be applied to strike down a term in a contract or to provide any other suitable remedy in order to ensure that practical justice is achieved. This case has the support of subsequent courts where this doctrine was applied in Standard Chartered Bank Malaysia Bhd v Foreswood Industries Sdn Bhd [2004] 6 CLJ 320 (HC), Low Sook Yee v Galaxy Music [2013] 3 AMR 358and Chua Yung Kim v Madlis bin Azid \& 97 others (http://www.kehakiman.gov.my/judgment/file/S-02-395-02-2012.pdf) (CA). However, none of these cases were dealing with the validity and enforcement of exclusion clauses.

\section{The Effect of the Consumer Protection (Amendment) Act 2010}

It was only in 2010 where the Malaysian Parliament enacted the Consumer Protection (Amendment) Act 2010 to include statutory provisions governing unfair terms as Part IIIA in the main Act. These new legal changes took effect on 1 February 2011. Although s.24B Consumer Protection Act 1999 (CPA 1999) provides that the law on unfair terms 'shall apply to all contracts', this is not entirely true. Since the law on unfair terms found in the CPA 1999, it would be subject to the scope of application of CPA 1999 as laid down in s.2 CPA 1999. The CPA 1999 applies to all goods and services that are offered to consumer(s) in trade. This would refer to contracts between businesses and consumers (B2C). Yet, the CPA 1999 would not apply to B2C contracts involving securities as defined in the Securities Industry Act 1983, land or interests in land, futures contracts, services provided by professionals who are regulated by any written law and healthcare services provided or to be provided by healthcare professionals or healthcare facilities. As such, there are plenty of B2C contracts which are outside the purview of the CPA 1999. It is also to be noted that the definition of 'professionals' regulated by 'written laws' is not expressly provided in the CPA 1999. This leaves room for argument as to the actual scope of the CPA 1999. The provisions in the CPA 1999 could not be contracted out (s.6 CPA 1999) and any ouster of jurisdiction of the courts to evade the operation of the CPA would be void (s.4 CPA 1999).

There are two separate grounds in which the validity of an exclusion clause can be challenged under the CPA 1999 i.e. (1) general procedural unfairness and (2) general substantive unfairness. 


\subsection{General Procedural Unfairness}

Section 24C(1) CPA provides that a contract or a term of contract is procedurally unfair if it results in an unjust advantage to the supplier or an unjust disadvantage to the consumer be referring to the manner and the circumstances in which the contract is created. There is a list of factors in which the court many take into account in determining this issue as seen in s.24C(2). Some examples of factors in this list include the knowledge of the consumer on the contents of the contract, the bargaining strength of the parties, reasonable standards of fair dealing, whether the terms are in fine print and difficult to understand and many more.

\subsection{General Substantive Unfairness}

The second ground of substantive unfairness focuses on the meaning of the terms. Section 24D(1) CPA 1999 states that a contract or a term would be substantively unfair if the contract or the term challenged is harsh, oppressive and unconscionable. Exclusion clauses would be substantively unfair if it excludes or restricts liability for negligence or excludes or restricts liability for breach of express or implied terms of the contract without adequate justification (s.24D(1)). S.24D(2) CPA 1999 provides a list of factors which the court may take into account in determining whether the term is substantively unjust. Some of these factors are whether the contract is oral or in writing, whether the benefits obtained by the consumer are manifestly disproportionate based on his circumstances, denies or penalises early repayment of debt and others. One conundrum posed is whether this list of factors applicable to exclusion clauses which exclude liability for negligence. This is because s.24D states clearly that a term is substantively unfair if it does so. There is arguably no room for exercise of discretion as to whether such term is substantively unfair or otherwise. If this argument is accepted, then any such exclusion clause in a B2C contract would be void (s.24G).

Section 24E provides that any supplier who wants to rely on a term of contract to exclude contractual liability, it has to prove that there is adequate justification for the inclusion of such a term. However the CPA 1999 does not define 'adequate justification'.

\subsection{Impact of Part IIIA CPA 1999}

The Part IIIA CPA 1999 does suffer from a number of weaknesses (Abu Bakar, Amin, 2016). Nonetheless, it does assist in strengthening the protection afforded to consumers despite its shortcomings. For instance, in Che Mohd Hashim Abdullah v Air Asia X Sdn Bhd (no:TTPM-WPPJ-(P)-10-2011), the contract to purchase online flight tickets contained the following clause:

"At any time after a booking has been made we may change our schedules and/or cancel, terminate, divert, postpone, reschedule or delay any flight where we reasonably consider this to be justified by circumstances beyond our control or for safety or commercial reasons. In the event of such flight cancellation, we shall either :

- carry you at the earliest opportunity an another of our scheduled services on which space is available without additional charge and where necessary, extend the validity of your booking; or

- should you choose to travel at another time, retain the value of your fare in a credit account for your future travel provided that you must re-book within 3 months therefrom; or

- offer a refund if we are unable to carry you to/from your destination within 48 hours from the scheduled time of departure.

The Tribunal of Consumer Claims decided that the above clause was unfair and Air Asia was ordered to pay compensation to the claimant for losses suffered due to the cancellation of flight.

As a result of the inclusion of Part IIIA in the CPA 1999, there are two regimes for the legal rules governing exclusion clauses in Malaysia, i.e. the CPA 1999 and the common law in instances where the 
CPA 1999 is not applicable. For example in ML Breadworks Sdn Bhd v Malayan Banking Bhd [2013] 1 CLJ 833, the High Court refused to allow the bank (defendant) rely on the exclusion clause found in the contract with its customer (plaintiff) as the bank was negligent and this caused loss to the plaintiff, applying the case of Chin Hooi Nan.

\section{Legal Position on Exclusion Clauses from 2014 onwards}

The year 2014 is chosen as this was the year the Federal Court case of CIMB Bank Bhd v Maybank Trustees Sdn Bhd [2014] 3 CLJ 1 has confirmed and reiterated the correct legal approach to be taken in determining the enforcement of exclusion clauses. In the case, the Federal Court unanimously agreed with the Court of Appeal where the proper approach to be adopted in relation to the effect and scope of an exclusion clause is by principles of construction of contract. The Federal Court stated that "the upholding or otherwise of the exemption clause agreed to by the parties depended upon the proper construction of that clause" by referring to the cases of Suisse Atlantique and Photo Production. If the exclusion clause is ambiguous, the principle of contra proferentem rule would apply where the court would adopt an interpretation which would be to the least advantage of the party who relies on the clause (Alisa Craig Fishing Co Ltd v Malvern Fishing Co Ltd [1983] 2 AC 803). However, if the clause is clear and unambiguous, the court would have to give effect to the meaning of the clause despite the possible unfair outcome of the particular case. There is no burden imposed on the party relying on the clause to prove that it has exercised due diligence or that it is not guilty of any misconduct. Nonetheless, in CIMB, the Federal Court held that an exclusion clause could not be operative to protect a party from its own fraud.

In United Overseas Bank (Malaysia) Bhd v Lee Yaw Lin [2016] 2 AMR 638, the Court of Appeal had to deal with an appeal regarding the issue of whether the defendant (bank) was liable for losses suffered by the plaintiff due to the burglary of the safe deposit boxes under the care of the defendant. The High Court disallowed the defendant from relying on the exclusion and limitation clause as it decided that the exclusion clauses were not incorporated into the contract and if the clause was given effect to, this would be 'making illusory the clear representations of safety and security offered by the banks in respect of safe deposit boxes'. The Court of Appeal disagreed with the High Court as it found that the exclusion clause had indeed been incorporated into the contract between the plaintiff and the defendant. The Court of Appeal applied the cases of Photo Production and Alisa Craig and held that the losses suffered and the cause of the losses were covered in the exclusion clauses and the defendant was not liable. In addition, the Court of Appeal opined that the hire of safe deposit boxes was an additional service offered by the bank to the convenience of its customers for a very modest amount of money. Given that the bank had no knowledge as to the contents kept at the safe deposit boxes, it was reasonable for the bank to exclude and limit liability for events beyond its control.

Although the Federal Court in CIMB did not expressly overrule cases like Chin Hooi Nan, the implication from the decision of CIMB is that the principle in Chin Hooi Nan should no longer be applicable. This was decided in the case of Clearpath Marketing Sdn Bhd v Malayan Banking [2017] AMEJ 0300. The High Court in Clearpath stated that the principle governing exclusion clauses in Malaysia is found in CIMB case. In Clearpath, the exclusion and limitation clause read as follows:

"I/We hereby agree that in no event will the Bank be liable for any lost profits, loss of business, loss of use, loss of goodwill, lost savings or other consequential, special, incidental, indirect, exemplary or punitive damages suffered by melus by reason o any delay in performance or non-performance of any obligations of the Bank whether arising from any negligence, breach of these terms or howsoever.

Notwithstanding anything to the contrary in these terms or conditions, the Bank's total liability hereunder however arising shall be limited to actual direct loss suffered by me/us (provided the same is supported by documentary evidence submitted by melus to the Bnak) which shall not exceed RM500.00 for all claims." 
Applying CIMB, the High Court in Clearpath held that the above exclusion clause was 'uncompromisingly clear and unambiguously expressed' and 'ought to be given full effect' despite the fact the plaintiff's opinion as to how unreasonable the clause was. Nonetheless, in this case, the plaintiff had failed to prove that the Bank (defendant) had breached its obligations.

From the above cases, the courts have lost one easy and convenient tool to control any possible abuse of the use of exclusion clauses. The hands of the courts are tied in that they would have to give effect to a broadly worded exclusion clause. Given the limitations of the scope of the law on unfair terms in the CPA 1999, there might arise many situations where the weaker party is prejudiced due to the enforcement of exclusion clauses. The courts do need to broach the existing law to determine how best to curb any potential abuse of exclusion clauses. This brings us to the case of CIMB Bank Bhd v Bourke [2019] 1 AMR 421.

\section{CIMB Bank v Bourke}

In Bourke, the plaintiffs were husband and wife and they were from United Kingdom. In 2008, they purchased a property in Malaysia and entered into a housing/shop house loan agreement with the defendant (bank). The property purchased was under construction. The defendant was under the obligation to release progressive payments on behalf of the plaintiffs to the developer upon the issuance of the certificate of completion for each stage of the construction. The defendant failed to pay the progressive payments in 2014 and the developer terminated the sale and purchase contract for the property in 2015. The plaintiffs pursued a legal action against the defendant to claim damages for losses suffered by the termination of the contract by relying on the ground of breach of contract and/or negligence. The defendant relied on Clause 12 of the loan agreement with provides that:

"Notwithstanding anything to the contrary, in no event will the measure of damages payable by the bank to the borrower for any loss or damage incurred by the borrower include, nor will the bank be liable for, any amounts for loss of income or profit or savings, or any indirect, incidental consequential exemplary punitive or special damages of the borrower, even if the bank had been advised of the possibility of such loss or damages in advance, and all such loss and damages are expressly disclaimed."

The plaintiff's claim failed at the High Court as it was held that Clause 12 had absolved the defendant from any liability for its breach of contract. The plaintiffs then appealed to the Court of Appeal which reversed the decision of the High Court. The Court of Appeal decided that Clause 12 was void as it went against s.29 Contracts Act 1950 as Clause 12 was treated as an ouster of the courts' jurisdiction (Bourke v CIMB Bank Bhd [2017] 4 AMR 725). Dissatisfied, the defendant appealed to the Federal Court which concurred with the decision of the Court of Appeal. A panel of five judges at the Federal Court in this case unanimously decided that (Judgment was delivered by Balia Yusof Wahi FCJ):

- The words in Clause 12 are clear and there is no need to resort to the contra proferentem rule. The principles in Photo Production were applied. But since whatever the plaintiffs were claiming was negated, this invoked the application of s.29. Thus, Clause 12 was void and unenforceable.

- In coming to this decision, the Federal Court applied the case of New Zealand Insurance Co Ltd v Ong Choon Lin [1992] 1 CLJ 230 (SC) and distinguished the case of Pacific Bank v Kerajaan Negeri Sarawak [2014] 2 AMCR 555.

- This case deserved the application of the principle of public policy as there would be patent injustice to the plaintiffs had Clause 12 been allowed. It was also unconscionable and an abuse of freedom of contract to allow the defendant to use Clause 12 as a shield against any claim.

- S.29 could only apply to defeat an exclusion clause if upon construction, the exclusion clause amounts to an 'absolute restriction' on the right of a plaintiff to claim for his losses. 
It is therefore necessary to evaluate legal reasoning provided for by the Federal Court in Bourke as this case might have far-reaching consequences.

\subsection{Evaluation of CIMB Bank v Bourke}

In order to evaluate the case of Bourke, the scope of s.29 shall first be discussed. Section 29 provides that:

Every agreement, by which any party thereto is restricted absolutely from enforcing his rights under or in respect of any contract, by the usual legal proceedings in the ordinary tribunals, or which limits the time which he may thus enforce his rights, is void to that extent.

The types of scenario covered by s. 29 as seen in decided cases are as follows:

- Agreement involves a promise or clause where one party agree not pursue any legal action arising from a transaction. The effect of such agreement is to oust the jurisdiction of the courts and is not allowed. As an example, in Nowran Begam Mohamed Saliff v Nantha Kumar Devar Sangaran [2016] 7 CLJ 760, a clause in the membership agreement where the plaintiff (deceased) agreed to waive any possible claim against the club was held to be void under s.29. similarly in Khor Chai Seang v Khor Teng Tong Holdings [2018] AMEJ 0419, an agreement where defendants had promised to pay the plaintiff a certain amount if he is to forebear or withhold any legal actions against the defendants were held to be void.

- Clauses which limit the time in which a party may enforce his rights. For instance in Ong Choon Lin and ALW Car Workshop Sdn Bhd v AXA Affin General Insurance Berhad, [2015] AMEJ 1518 , a clause provided that 'In no case whatever shall the company be liable for any loss or damage after the expiration of 12 months from the happening of loss or damage unless the claim is subject of pending action or arbitration.'. This clause was void. In MBF Insurance Sdn Bhd v Lembaga Penyatuan dan Pemulihan Tanah Persekutuan (FELCRA) [2008] 2 MLJ 32 (FC), the insurance contract provided that 'the guarantee will expire on 14 June 1991. Claims, if any, must be received on or before this date'. The Federal Court decided that this clause was void.

The above discussion shows that scenarios involving exclusion clauses are not within the scope of s.29. In fact, s.29 deals with ouster of the courts' jurisdiction which is similarly prohibited in other common law countries, such as England, Australia, Canada and Singapore. This means that there are terms in the contract between the parties which deprive the aggrieved party from the right to seek the courts' intervention in the dispute faced by them. Such clauses are illegal and void due to public policy. It is interesting to note that none of these countries treat exclusion clauses as equivalent to ouster of the courts' jurisdiction despite how broadly worded the exclusion clause is (Choong, 2019). Andrew Phang JA in the decision of the Singaporean Court of Appeal in CKR Contract Services Pte Ltd [2015] SGCA 24 had put it succinctly where the learned judge stated that:

“. . limitations placed on the rights and remedies available to the parties have not been treated as an ouster of the courts' jurisdiction. For example, parties are at the liberty to seek to limit or even exclude altogether an innocent party's right to damages in the event of a breach of contract by the other party. Clauses which attempt to do so are . . either limitation clauses or exclusion clauses. . . What is clear, however, is that such clauses have never been treated as being void and unenforceable as clauses seeking to oust the jurisdiction of the court; after all neither party has been denied access to the court as such." (emphasis added)

The above observation is in stark contrast with the decision of the Federal Court in Bourke. Balia Yusof Wahi FCJ justified his decision based on the following points: 
The decision of CKR Contract Services was distinguished from the facts of Bourke. In CKR Contract Services, the issue which arose was whether a clause in a performance bond which excluded the principle of unconscionability in a party's right to restrain a call on the performance bond was void as an ouster of the court's jurisdiction. The Singaporean Court of Appeal decided otherwise and held that the clause was enforceable and binding on the parties.

Although there are material differences between the facts of CKR Contract Services and Bourke, yet the statement by Andrew Phang JA as produced above refers to the general principles of contract law where an exclusion clause is not treated as an ouster of the court's jurisdiction. With due respect, the FC in Bourke which decided otherwise seems to run counter to the general principles of contract law as applied in other countries.

The Federal Court in Bourke relied on the principle in Ong Choon Lin and MBF Insurance where the Supreme Court in the latter case held that:

"This distinction between the existence of a right and its enforcement as a matter if law does not however appear to exist in our jurisprudence as can be seen in the judgment of this court in Hock Hua Bank Bhd v Leong Yew Chin [1987] 1 MLJ 230."

Despite acknowledging the factual differences between Ong Choon Lin and Bourke, yet the Federal Court in Bourke applied this principle to exclusion clauses which therefore amounted to ouster of the courts' jurisdiction. This is different from the general principles of contract law which disallow parties from ousting the courts' jurisdiction (not allowed to insert a term to forbid the right to pursue a legal action) but allowed the contracting parties to exclude possible remedies arising from the outcome of a legal action as seen above.

The support and application of Ong Choon Lin and MBF Insurance raise a few difficulties. First, the possible application of Ong Choon Ling and MBF Insurance had been limited by the Federal Court decision in Pacific Bank Bhd v Kerajaan Negeri Sarawak [2014] 5 AMR 228. In Pacific Bank, it was held unanimously that the courts 'should be mindful' in following the decisions in MBF Insurance and Ong Choon Lin. The Federal Court justified the outcome of these two decisions as these cases involved insurance contracts which are uberrimae fidei contracts (utmost good faith). This was because the plaintiff had paid premium to purchase protection from the defendant and it would be bad faith on the part of the defendant to avoid liability by limiting the time in which the plaintiff was entitled to bring a claim which was shorter that the period allowed by the law. A contract between a bank and its customers such as that in Bourke is not a uberrimae fidei contract. Unfortunately, the Federal Court in Bourke stated that the Pacific Bank case was inapplicable as the issue on the differences between rights and remedies was not dealt with in the latter case.

Secondly, the cases of Ong Choon Lin and Hock Hua Bank did not relate to exclusion clauses. In Hock Hua Bank, the Supreme Court decided that it had power to grant an amendment to the pleadings after the expiry of the limitation period notwithstanding that the effect of the amendment would be to add or substitute a new cause of action, subject to the very important condition, namely that the new cause of action must arise out of the same or substantially the same facts as the cause of action in respect of which relief had already been claimed. The reason was due to the fact that relief or remedy is not dissociated with the right of action. Besides, the statement that there is no difference between right and remedy in Ong Choon Lin was to enable the plaintiff to have recourse in the courts which they would have had if not for the existence of the term limiting the time in which he could pursue a legal action. What is important to note here was that the law allows a limitation period of six years. Thus, the clause attempted to go against the law. On the contrary, the provision of exclusion clauses is allowed by the law. Perhaps, the Federal Court was aware of this difficulty and held that s.29 could only be invoked in situations where there is 'absolute restriction' of the plaintiff's right to remedies. The Federal Court held that due to Clause 
12, any legal action taken by the plaintiff would be an 'exercise in futility' as the plaintiff would not be able to obtain any damages from the defendant. The Federal Court looked at the practical effects of the clause to render Clause 12 void as an ouster of the court's jurisdiction. Again, there are difficulties with the novel approach enunciated by the Federal Court.

The issue as to whether the exclusion clause amounting to an 'absolute restriction' would depend on construction of the exclusion clause. This would depend on the approach taken to construe the exclusion clause. Different outcome might arise. For instance, the Federal Court in Bourke decided that Clause 12 amounted to 'absolute restriction'. On the contrary, Choong (2019) and Chai (2019) reached the opposite conclusion and claimed that there are some losses not covered by Clause 12 such as direct losses and wasted expenditure. In addition, Clause 12 only excluded damages but there was no mention on the remedies of injunction or specific performance. This means that a legal action can still be pursued for these two remedies. Looking from this perspective, Clause 12 did not 'oust the jurisdiction' of the courts completely.

\subsection{Possible Impact of CIMB Bank $v$ Bourke to Business Practices and Subsequent Cases on Exclusion Clauses}

It is undoubted that the outcome of the decision of Bourke is fair. It indeed received much praise and attention (The Star, 18 December 2018, The Star, 14 January 2019). Based on the Federal Court decision in Bourke, businesses should review the exclusion clauses that they provide for in their contracts amount to 'absolute restriction' and if so, there is a need to review the scope of the exclusion clauses to ensure that these clauses do not go against the law. Nonetheless, it remains to be seen whether businesses would take this effort or would rather maintain the status quo position. For instance, in ALW Car Workshop, the court lamented that despite the similar clause used in this case was held to be void in Ong Choon Lin in 1991, yet there are insurance companies which continue to provide such clause in their insurance policies.

It is also remains to be seen as to whether the decision in Bourke would increase the amount of litigation on the validity of exclusion clauses. Many consumer contracts would fall within the purview of the CPA 1999 where the courts or Tribunal for Consumer Claims in Malaysia can resort to Part IIIA CPA 1999 to determine the validity of exclusion clauses. Furthermore, the Federal Court in Bourke had limited the application of s.29 to exclusion clauses which amount to 'absolute restriction'. The Federal Court in Bourke also noted that the facts of Bourke warranted the application of the principle of public policy as the plaintiffs and defendant were not of equal bargaining power and added that it 'is unconscionable on the part of the defendant (bank) to seek refuge behind the clause and an abuse of the freedom of contract'. It is uncertain whether the principle of unequal bargaining power only applies to cases involving private individuals contracting in their personal capacity or whether it would be extended to small businesses. This is crucial as there are no statutory rules controlling the use of exclusion clauses in B2B contracts despite the fact that one of the parties involved is a small business and the contract is a standard contract where there is no room for bargaining.

\section{Conclusion}

Due to the Federal Court decision in Bourke, the legal saga of exclusion clauses in Malaysia is far from over. The novel approach propounded by the Federal Court in Bourke is at odds with the general principles of contract law as adopted by other common law countries. This might affect the legal coherency of contract law in Malaysia and there are also uncertainties arising from this novel approach. For instance, there is no clear guidance as to what amount to 'absolute restriction' as seen above. Although the outcome of Bourke is commendable and proved that the Malaysian courts exercise vigilance to ensure that the concept of freedom of contract is not abused, one wonders whether the court could have relied on other recognized principles to reach similar result such as by relying on the doctrine of unequal bargaining power in Saad Marwi or restrict the application of the exclusion clause via principles of construction (Choong, 2019). The decision of Bourke clearly shows that more could have been done to protect consumers and other private individuals due to the limitations placed on the scope of the CPA 
1999. It is hoped that in the near future, the Federal Court would have an opportunity to review its own decision in Bourke and the Parliament would moot the idea of extending statutory protection against unfair terms to larger groups of transactions. This would certainly be in line with the development undertaken in other countries.

\section{References}

Abu Bakar, E, Amin, N. (2016). Consumers' Awareness and Practices Towards 'Exclusion Clause' and its Position under Malaysian Law. Malaysian Journal of Consumer and Family Economics: 15-25.

Chai, P.Y. (2019) No more Exclusion Clauses in Malaysia? http://www.ccalaw.com/index.php/home/knowledge/article/item/no-more-exclusion-clauses-inmalaysia-2

Choong, S.M. (2018). Can a Mere Exclusion Clause be Considered an Ouster of the Courts' Jurisdiction? University Malaya Law Review, http://www.umlawreview.com/lex-in-breve/can-a-mereexclusion-clause-be-considered-an-ouster-of-the-courts-jurisdiction (

Choong, S.M. (2019). An Exclusion Clause Wrongly Ousted. University Malaya Law Review, http://www.umlawreview.com/lex-in-breve/an-exclusion-clause-wrongly-ousted-a-well-draftedexclusion-clause-misinterpreted-on-many-levels

The Star, 'Ruling a triumph against banks' exclusion clauses' 18 December 2018 https://www.thestar.com.my/news/nation/2018/12/18/lawyer-ruling-a-triumph-against-banksexclusion-clause

The Star, 'Unconscionable for banks to seek refuge behind exclusion clauses' 14 January 2019 https://www.thestar.com.my/business/business-news/2019/01/14/unconscionable-for-banks-toseek-refuge-behind-exclusion-clauses 